\title{
Keefektifan Teknik Self Instruction dalam Konseling Kognitif-Perilaku untuk Meningkatkan Efikasi Diri Sosial Siswa SMKN 2 Malang
}

\author{
Fitri Aryadini Dewi, Adi Atmoko, Triyono \\ Jurusan Bimbingan dan Konseling-Fakultas Ilmu Pendidikan-Universitas Negeri Malang- \\ Jl.Semarang No. 5, Malang, Jawa Timur 65145 \\ E-mail: faryadini@yahoo.com
}

Artikel diterima: 2 Juni 2016; direvisi 29 Desember 2016; disetujui: 29 Desember 2016

\begin{abstract}
This study aims to determine the effectiveness of self instruction technique in cognitive behavior counseling to improve the self efficacy in social relation of vocational students. This experimental study using Single Case Experimental Design (SCED) model of the A-B-A'. The subject of research are three students of SMKN 2 Malang which show a low level of self efficacy social based on the scale of self efficacy social. The research instrument used as scale self efficacy social with the validity $\geq 0.3$ and reliability 0,883 , observation guidelines, and counseling guidelines. The results showed that subjects experienced an increase in social self-efficacy after a treatment given. Data has been analyzed using a visual inspection showed significant changes, so that it can be concluded self-instruction techniques in cognitive behavioral counseling is effective to improve student's social self-efficacy SMKN 2 Malang.
\end{abstract}

Keywords: self instruction; cognitive behavior counseling; social self-efficacy; SMKN 2 Malang

\begin{abstract}
Abstrak: Penelitian ini bertujuan mengetahui keefektifan teknik self instruction untuk meningkatkan efikasi diri sosial siswa SMKN 2 Malang. Penelitian eksperimen ini menggunakan metode Single Case Experimental Design (SCED) model A-B-A'. Subjek penelitian berjumlah tiga siswa kelas X di SMKN 2 Malang yang menunjukkan tingkat efikasi diri sosial rendah berdasarkan skala efikasi diri-sosial. Instrumen penelitian yang digunakan adalah skala efikasi diri sosial dengan validitas butir $\geq 0,3$ dan realibilitas 0,883 , pedoman observasi, dan pedoman konseling. Hasil penelitian menunjukkan bahwa subjek mengalami peningkatan efikasi diri sosial setelah diberikan treatment. Data yang telah dianalisis menggunakan visual inspection menunjukkan perubahan secara signifikan, sehingga dapat disimpulkan teknik self instruction dalam konseling kognitif-perilaku efektif untuk meningkatkan efikasi diri sosial siswa SMKN 2 Malang.
\end{abstract}

Kata kunci: self instruction; konseling kognitif-perilaku; efikasi diri sosial; SMKN 2 Malang

Manusia dituntut untuk dapat mengadakan jalinan hubungan dengan anggota keluarganya, teman sebaya, rekan kerja, karyawan dan sebagainya. Masih banyak manusia yang kesulitan untuk menjalin hubungan sosial sesuai dengan yang mereka butuhkan. Terlihat masih banyak manusia yang cenderung tersisihkan dari pergaulan dan tidak mampu berinteraksi dengan manusia lain. Hal ini bisa terjadi pada semua jenjang usia, terlebih banyak terjadi pada masa remaja. Menurut Hurlock (1980) masa remaja disebut sebagai " problem age" hal ini dapat dipahami karena pada masa remaja terjadi transisi sosialisasi dari masa kanak-kanak ke masa dewasa. 
Siswa SMK yang berada pada periode perkembangan dan masa remaja yaitu usia 15-18 tahun mengalami pertumbuhan dan perkembangan yang pesat baik fisik dan psikis. Kesulitan siswa SMK dalam menjalin hubungan sosial juga dipengaruhi oleh berbagai faktor yaitu: (1) lingkungan SMK yang merupakan bentuk lingkungan heterogen. SMK dikatakan lingkungan heterogen karena mempunyai peminatan atau jurusan yang lebih banyak daripada tingkat pendidikan lainnya. (2) mata pelajaran yang lebih banyak dan lebih kompleks daripada jenjang lainnya dan (3) pendidikan SMK yang lebih mengarah ke arah pekerjaan atau karier. Selain faktor dari lingkungan SMK tersebut ada faktor internal dari diri yaitu para remaja terbentur dengan persepsi dan keyakinan dalam dirinya.

Bandura (1997) mengatakan bahwa efikasi diri menjadi faktor penentu tindakan manusia melalui proses kognitif. Efikasi diri merupakan salah satu aspek pengetahuan tentang diri atau self knowledge yang paling berpengaruh dalam kehidupan manusia sehari-hari. Hal ini disebabkan efikasi diri yang dimiliki memengaruhi individu dalam menentukan tindakan yang akan dilakukan untuk mencapai suatu tujuan termasuk di dalamnya perkiraan berbagai kejadian yang akan dihadapi. Keyakinan tentang sejauh mana individu memperkirakan kemampuan dirinya termasuk potensipotensi yang dimilikinya untuk melakukan tugas-tugas yang dibutuhkan terhadap kehidupan sosialnya, disebut efikasi diri dalam hubungan sosial.

Dalam membantu siswa mencapai tugas perkembangan, ada beberapa kegiatan yang dapat dilakukan sebagai bentuk layanan bimbingan dan konseling, salah satunya kegiatan yang dapat dilakukan adalah layanan konseling. Banyak pendekatan konseling yang dapat digunakan dalam pemberian layanan kepada siswa, baik dalam konseling individu maupun konseling kelompok. Salah satunya adalah konseling kognitif-perilaku atau sering dikenal dengan cognitive behavior therapy. Fokus dari konseling kognitif individu terletak pada pikiran, asumsi dan keyakinannya. Dengan konseling kognitif, individu diarahkan untuk mengidentifikasi, mengevaluasi dan menantang pola pikir yang salah atau maladaptif. Dengan merubah status pikiran dan perasaannya, individu diharapkan dapat merubah tingkah lakunya dari negatif menjadi positif. Pendekatan ini merupakan bentuk konseling yang ingin melihat individu tidak hanya dipahami melalui perilakunya yang tampak saja, namun dibalik tingkah laku yang tampak terdapat proses internal yang sebenarnya merupakan hasil pemikiran kognisi. Salah satu teknik yang ada pada modifikasi konseling kognitif-perilaku adalah self instruction.

Teknik self instruction merupakan salah satu teknik yang terdapat di dalam pendekatan cognitive behavior modification yang dikembangkan oleh Meinchenbaum (Corey, 2009:296). Perilaku maladaptif dipengaruhi oleh pikiran irasional yang menyebabkan verbalisasi diri yang tidak tepat (Baker \& Butler: dalam Nurbaity, 2012:27). Inti dari teknik adalah membangun kembali sistem kognisi konseli, namun terpusat pada pola verbalisasi overt (disuarakan secara lantang/ keras) dan covert (disuarakan dalam hati). Sedangkan menurut Jones (2011:638) self instructional training merupakan suatu usaha yang dilakukan oleh terapis atau konselor untuk melatih konseli agar dapat mengganti pernyataan negatif tentang dirinya dengan pernyataan positif berorientasi tugas yang memfasilitasi coping.

Dalam pelaksanaannya, konselor dapat berperan sebagai model perilaku yang tepat untuk konseli dimana konseli mendengarkan secara seksama dan mempraktikkan model perilaku yang dilakukan oleh konselor. Selanjutnya konseli mengulangi instruksi pada diri mereka sendiri sampai konseli merasa mampu untuk melakukannya. Untuk mempermudah, konseli dapat mencatat harapan-harapan positif mereka pada lembar kerja untuk selanjutnya mengintruksikannya untuk diri mereka sendiri. Dapat dikatakan bahwa teknik self instrucion memberikan keterampilan pada individu untuk menangani secara efektif situasi yang dirasa sulit baginya.

\section{METODE}

Rancangan penelitian yang digunakan adalah Single Case Experimental Design (SCED) dengan model A-B-A'. Subjek penelitian sebanyak tiga siswa di SMKN 2 Malang yang menunjukkan tingkat efikasi diri sosial rendah berdasarkan skala efikasi diri sosial. Penentuan siswa sebagai 
subjek penelitian menggunakan skala efikasi diri sosial, hasilnya diperoleh tiga orang siswa dari kelas X yang menunjukkan skor efikasi diri sosial rendah. Masing-masing siswa diinisialkan sebagai subjek FDM, subjek EP, dan subjek SR. Skala efikasi diri sosial merupakan salah satu instrumen penelitian yang digunakan untuk menentukan siswa sebagai subjek penelitian. Instrumen penelitian yang lain adalah pedoman konseling dan pedoman observasi. Pedoman eksperimen dikembangkan sebagai panduan dalam melaksanakan teknik self instruction dalam konseling cognitive behavior, sedangkan pedoman observasi digunakan untuk mengetahui perkembangan perilaku efikasi diri sosial siswa terhadap treatment yang diberikan. Observasi dilakukan tiga kali pada tiap fase A, fase A' dan enam kali pada fase B. Pelaksanaan teknik self instruction dalam konseling kognitifperilaku terdiri dari empat tahapan pokok yaitu, self instruction untuk meningkatkan kepercayaan dalam situasi yang tak menentu dalam hubungan sosial, self instruction untuk meningkatkan keyakinan diri dalam mengatasi masalah yang muncul dalam hubungan sosial, self instruction untuk meningkatkan keyakinan diri dalam mencapai target yang ditetapkan, self instruction untuk meningkatkan keyakinan diri akan kemampuan menggerakkan tindakan dalam hubungan sosial. Keempat tahapan tersebut dijabarkan menjadi enam sesi pertemuan konseling dengan 30-45 menit tiap sesinya. Analisis data yang digunakan adalah visual inspection berupa grafik yang menggambarkan hasil observasi pada fase A, fase B dan fase A', selain itu data hasil observasi juga diolah dalam bentuk persentase untuk menunjukkan peningkatan efikasi diri sosial pada setiap subjek penelitian.

\section{HASIL}

Data perkembangan efikasi diri sosial subjek terhadap treatment yang diberikan diperoleh dari hasil observasi. Observasi dilakukan tiga kali pada fase A dan fase A' untuk mengetahui perubahan efikasi diri sosial subjek penelitian. Pengambilan data efikasi diri sosial dilakukan pada saat siswa di dalam kelas mengikuti kegiatan pembelajaran dan saat istirahat berlangsung. Kegiatan ini dilakukan pada waktu, tempat, dan subjek yang sama.

Observasi pada fase A dapat diketahui gejala efikasi diri sosial siswa dari perilaku yang ditunjukkan. Subjek FDM menunjukkan gejala efikasi diri sosial yang rendah seperti siswa menyendiri, jarang berkomunikasi dengan temannya, ketika istirahat siswa juga jarang sekali membaur dengan teman yang lain. Dari hasil observasi menunjukkan bahwa subjek EP pendiam, jarang berkomunikasi dengan teman-temannya, sering duduk sendirian ketika istirahat. Subjek SR dalam hubungan sosial terlihat menyendiri, subjek hanya diam ketika guru bertanya, jarang berkumpul dengan teman yang lain. Ketiga subjek menunjukkan gejala rendahnya efikasi diri sosial yang bervariasi meski beberapa tingkah laku ada yang sama. Begitu juga pelaksanaan treatment, sesuai dengan pedoman konseling sesi pertemuan konseling yang terukur sebanyak enam kali. Dalam pelaksanaannya, ada sesi konseling yang berlangsung sampai lebih dari enam kali.

Pengukuran kembali dilakukan pada fase A' setelah pemberian treatment dengan observasi. Gejala perilaku efikasi diri sosial siswa mulai berkurang bahkan subjek terlihat lebih aktif dalam pembelajaran di kelas maupun berinteraksi dengan teman, hal ini menunjukkan adanya peningkatan efikasi sosial siswa.

Berdasarkan Gambar 1, grafik subjek FDM menunjukkan adanya peningkatan perilaku efikasi diri-sosial yang cukup signifikan. Pada setiap fase A, B, A' juga menunjukkan peningkatan meskipun sedikit demi sedikit. Gambar 2 merupakan grafik subjek EP yang menunjukkan bahwa ada peningkatan perilaku efikasi diri-sosial yang signifikan. Pada setiap fase A, B dan A' juga menunjukkan peningkatan perilaku efikasi diri-sosial. Gambar 3 adalah grafik subjek SR yang menunjukkan adanya peningkatan perilaku efikasi diri-sosial yang cukup signifikan. Pada fase A menunjukkan penurunan perilaku, sedangkan pada fase $\mathrm{B}$ menunjukkan peningkatan meskipun terjadi penurunan pada observasi ke enam dan pada fase A' juga menunjukkan peningkatan perilaku efikasi diri-sosial. 


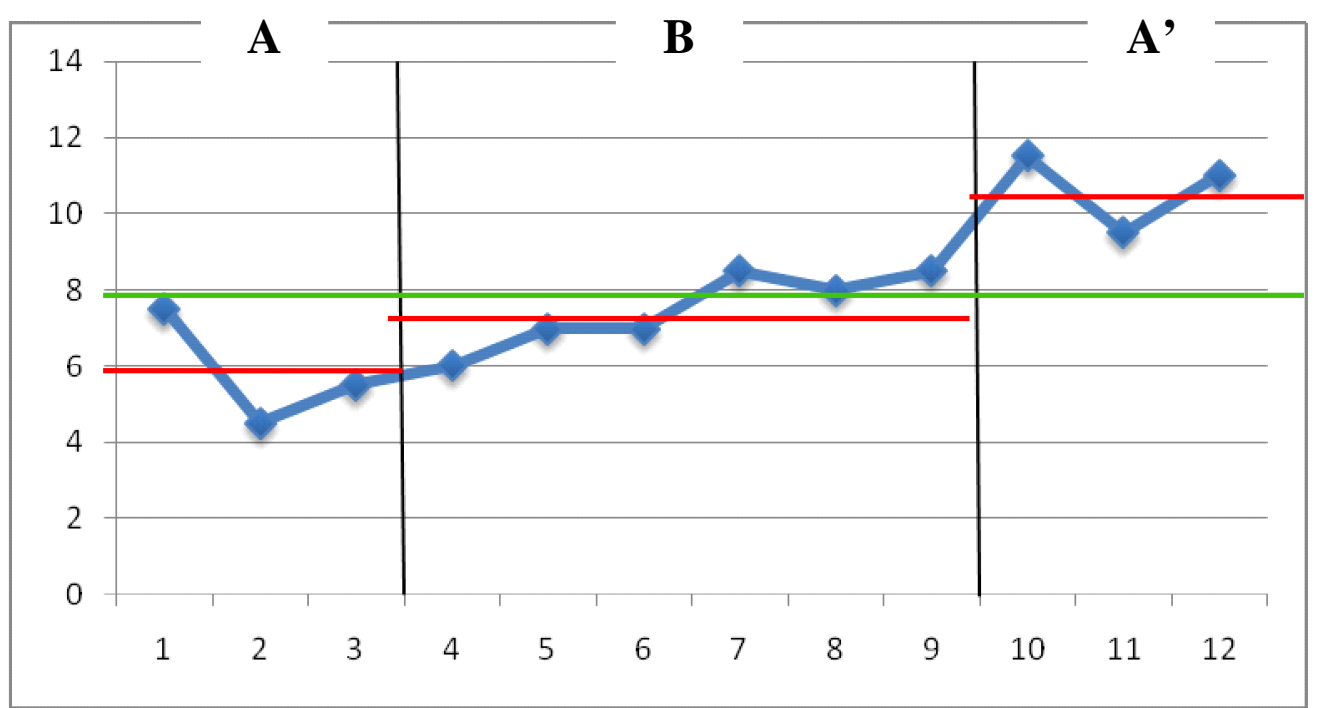

\section{Gambar 1. Grafik Subjek FDM}

Keterangan :
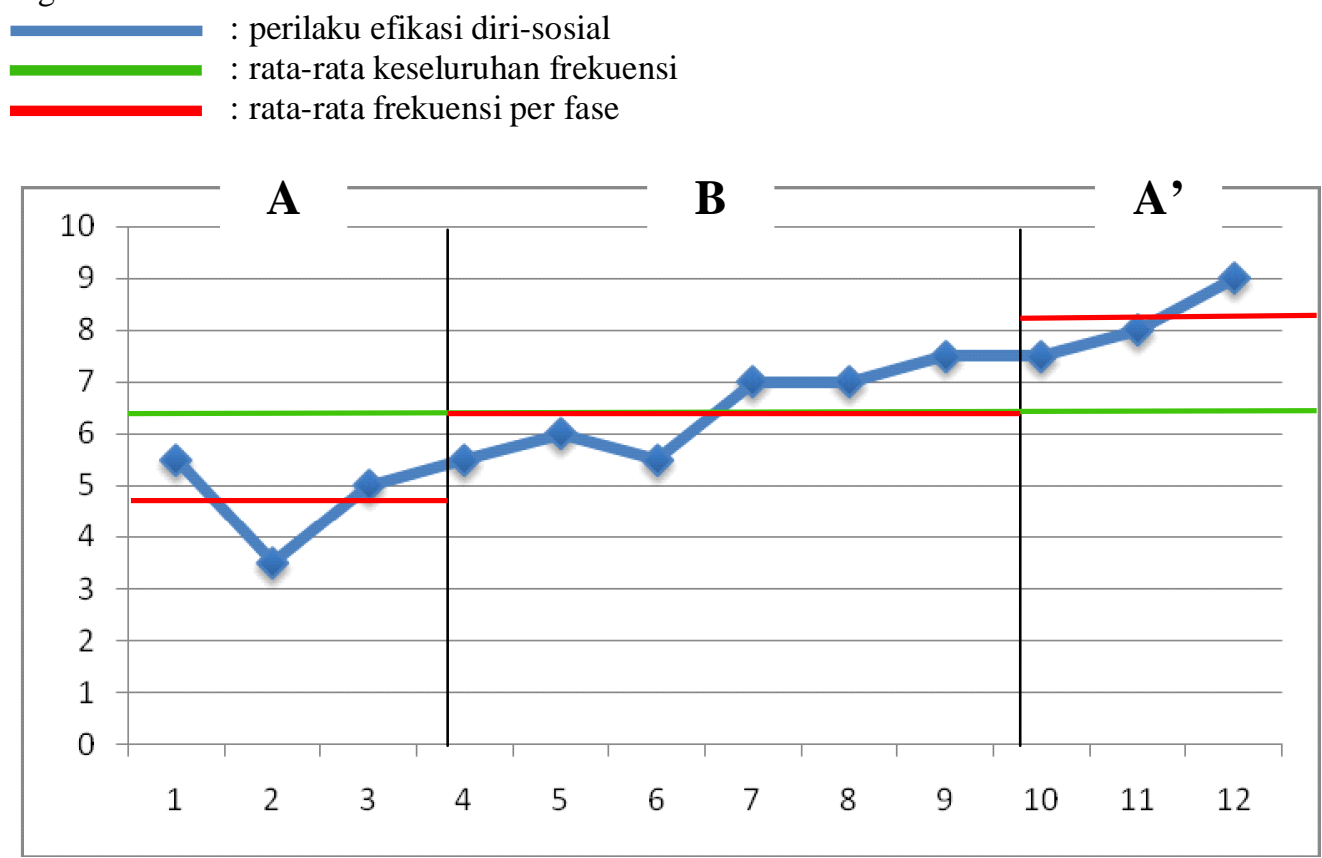

\section{Gambar 2. Grafik Subjek EP}

Keterangan :

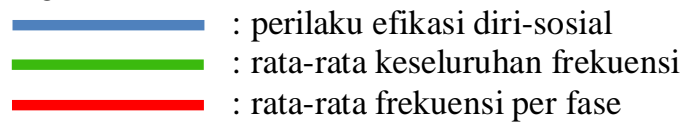

Data menunjukkan hal yang sama, terjadi peningkatan pada tiap subjek penelitian meski persentasenya tidak sama. Subjek FDM mengalami peningkatan terjadi sebesar $82,85 \%$. Subjek EP, meski perubahan yang terjadi lebih sedikit jumlahnya daripada subjek FDM, tetap menunjukkan angka di atas $50 \%$ yaitu $75 \%$. Subjek SR menunjukkan perubahan sebesar 66,6\%. Mengacu pada kriteria yang dikemukakan oleh Goodwin dan Coates (1986) bahwa pengubahan tingkah laku 
A

B

A

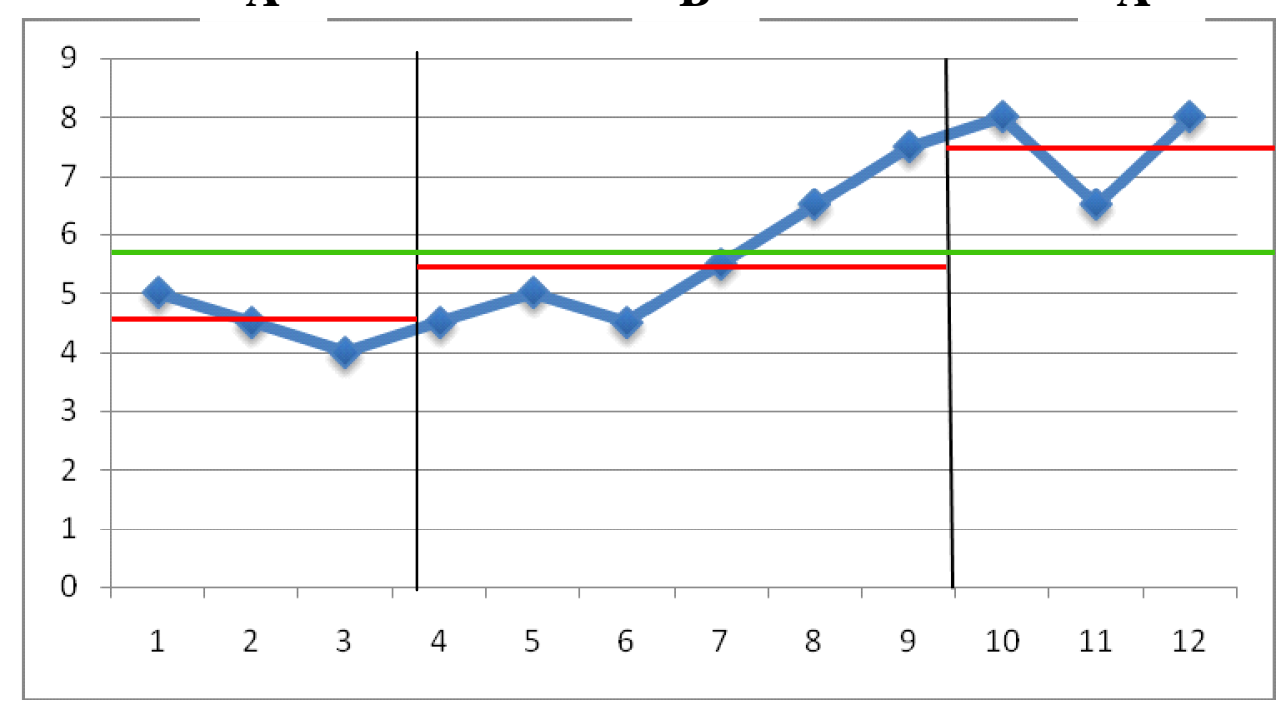

\section{Gambar 3. Grafik Subjek SR}

Keterangan :

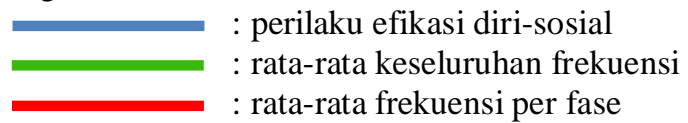

dinyatakan berhasil atau efektif jika perilaku efikasi diri-sosial siswa tidak kurang dari $50 \%$. Dengan demikian dapat disimpulkan bahwa teknik self instruction dalam konseling kognitif-perilaku efektif untuk meningkatkan efikasi diri sosial siswa SMKN 2 Malang.

\section{PEMBAHASAN}

Perbedaan hasil peningkatan efikasi diri sosial setiap subjek berbeda walaupun diberikan perlakuan serupa dikarenakan setiap subjek mempunyai karakteristik yang berbeda. Ada subjek yang mempunyai karakteristik memang mudah bersosialiasi dan subjek yang memang cenderung lebih pendiam. Selain itu, harapan dan keyakinan positif setiap siswa dalam mengikuti proses konseling yang berbeda juga memengaruhi hasil peningkatan. Ada subjek yang cenderung tidak aktif dan tidak mempunyai harapan besar untuk meningkatkan efikasi dirinya. Perbedaan karakter ini dapat memengaruhi hasil peningkatan setiap subjek, karena dalam pengukuran menggunakan lembar observasi, beberapa aspek yang dapat diamati secara langsung berhubungan dengan interaksi sosial. Subjek yang cenderung pendiam, hasil pengukurannya akan lebih rendah dibanding subyek yang cenderung aktif. Bisa dikatakan juga bahwa peningkatan efikasi diri sosial juga dipengaruhi oleh karakteristik dari subjek itu sendiri. Secara umum, masalah efikasi diri sosial di sekolah yang dialami oleh siswa tidak hanya dikarenakan faktor dari dalam diri saja, tetapi pengaruh keluarga dan keadaan lingkungan sekitar mempunyai dampak yang cukup besar. Berada pada lingkungan yang terdiri dari berbagai macam karakter orang, lingkungan, dan aturan yang harus diikuti, mengharuskan seseorang untuk bisa beradaptasi dengan lingkungan sosial yang berbeda.

Berdasarkan subjek penelitian ini, efikasi diri sosial siswa di sekolah juga membawa pengaruh terhadap prestasi akademik. Siswa yang mengalami masalah efikasi diri sosial rendah cenderung lebih tertutup, pendiam, apatis terhadap sekitar, dan prestasi belajar yang menurun bahkan rendah. Menurut Santrock (2002) agar hubungan sosial yang dilakukan terhadap lingkungan sosial berhasil (well adjusted), maka remaja harus menyelaraskan antara tuntutan yang berasal dari dalam dirinya dengan tuntutan yang diharapkan oleh lingkungannya, agar mereka mendapatkan kepuasan dan memiliki kepribadian yang sehat. Untuk itu remaja harus mengetahui lebih banyak informasi yang 
tepat tentang diri dan lingkungannya. Selain itu, masalah yang terjadi di rumah sering memengaruhi keadaan efikasi diri sosial siswa ketika di sekolah.

Upaya yang diberikan kepada siswa untuk membantu meningkatkan efikasi diri dalam hubungan sosial di sekolah dengan melakukan teknik self instruction menggunakan konseling kognitifperilaku. Penekanan utama konseling kognitif-perilaku berada pada merestrukturisasi kognitif yang menyimpang dan sistem kepercayaan untuk membawa perubahan emosi dan perilaku ke arah yang lebih baik. Teknik self instruction merupakan salah satu teknik yang terdapat di dalam pendekatan cognitive behavior modification yang dikembangkan oleh Meinchenbaum (Corey, 2009:296). Menurut Jones (2011:638) self instructional training merupakan suatu usaha yang dilakukan oleh terapis atau konselor untuk melatih konseli agar dapat mengganti pernyataan negatif tentang dirinya dengan pernyataan positif berorientasi tugas yang memfasilitasi coping. Dengan kata lain, teknik self instruction dalam konseling kognitif-perilaku ini membantu siswa untuk mengubah pikiran dan keyakinan yang negatif menjadi lebih positif. Perilaku maladaptif dipengaruhi oleh pikiran irasional yang menyebabkan verbalisasi diri yang tidak tepat (Baker \& Butler: dalam Nurbaity, 2012:27). Seperti siswa yang memiliki efikasi diri sosial yang rendah akan cenderung memiliki perilaku yang manarik diri dari lingkungan seperti menyendiri, pendiam, dan kurang berinteraksi dengan orang lain di lingkungan sekolahnya.

Penelitian ini juga dapat dijadikan referensi bagi kinerja konselor di sekolah tentang bagaimana membantu permasalahan siswa. Meski siswa memiliki efikasi diri sosial yang sama-sama rendah, tetapi ternyata faktor yang memengaruhi efikasi diri tersebut bisa berbeda-beda pada tiap individunya. Hal ini menuntut konselor untuk bisa mengenal dan memahami siswa secara utuh sesuai dengan karakteristiknya. Sejalan dengan pernyataan dari Gibson \& Mitchell (2008) tentang hubungan konseling dan profesi penolong, konseling berlandaskan kemampuan pembedaan karakteristik manusia dan berusaha membantu individu mencapai realisasi diri mereka. Konseling mestinya berakar pada pemahaman mengenai karakteristik dan kebutuhan semua konseli serta pemahaman tentang lingkungan yang telah membentuk mereka. Sehingga konselor hendaknya mempelajari pertumbuhan dan perkembangan manusia dan faktor sosial budayanya.

Beberapa penelitian serupa pernah dilakukan yang menunjukkan keefektifan teknik self instruction dalam lingkup sekolah. Seperti penelitian yang dilakukan oleh Widiyanti (2013) melalui teknik self instruction konseli diajarkan untuk mengubah pola verbalisasi dirinya dengan mengubah pikiran negatif menjadi positif agar menghasilkan perilaku dalam belajar yang lebih adaptif. Penelitian lain juga dilakukan oleh Prasetyo (2013) perubahan kecemasan menghadapi ujian dengan teknik self instruction tersebut ditunjukkan dengan perubahan kategori kecemasan dari kategori tinggi ke kategori sedang atau rendah. Meski perubahan yang terjadi bervariasi pada setiap siswa, secara umum semua menunjukkan penurunan tingkat kecemasan siswa. Hasil penelitian ini dibandingkan dengan penelitian terdahulu yang serupa, menunjukkan bahwa teknik self instruction efektif untuk membantu beberapa masalah siswa dalam lingkup sekolah. Keberhasilan teknik self instruction ini juga relatif pada setiap subjek penelitian, hal ini juga ditunjang karena metode penelitian yang digunakan hampir sama. Bisa dikatakan bahwa, pikiran atau keyakinan seseorang yang telah terbentuk bisa diubah dan dibentuk kembali.

\section{SIMPULAN}

Dari penelitian tentang keefektifan teknik self instruction untuk meningkatkan efikasi diri sosial siswa ini dapat disimpulkan bahwa, teknik self instruction dalam konseling kognitif-perilaku efektif untuk meningkatkan efikasi diri sosial siswa SMKN 2 Malang.

Berdasarkan penelitian eksperimen tentang keefektifan teknik self instruction untuk meningkatkan efikasi diri sosial siswa di sekolah, terdapat beberapa saran yang dapat menjadi pertimbangan bagi konselor dan peneliti selanjutnya. Konselor dapat menggunakan teknik self instruction, dengan memerhatikan karakteristik siswa yang mirip dengan subjek penelitian dan menggunakan pedoman konseling yang telah dibuat dapat untuk mempelajari pelaksanaan teknik 
self instruction dalam konseling kognitif-perilaku. Sedangkan peneliti selanjutnya dapat melakukan penelitian eksperimen dengan menggunakan kelompok kontrol atau penelitian tindakan bimbingan dan konseling dan dapat menggunakan self instruction dalam konseling kognitif-perilaku untuk membantu siswa yang mengalami masalah dalam lingkup sekolah.

\section{DAFTAR RUJUKAN}

Bandura, A. 1997. Self-Efficacy: The Excercise of Control. New York:W.H.Freeman and Company.

Corey, G. 2009. Theory and Practice of Counseling and Psychotherapy: Eighth Edition. USA: Brooks/Cole A Devision of Cengange Learning, Inc Amerika.

Gibson, R. L. \& Mitchell, M. H. 2008. Bimbingan dan Konseling. Yogyakarta: Pustaka Pelajar. Goodwin, D. L. \& Coates, T.J. 1976. Helping Students Help Themselves. Englewood Cliff. New Jersey: Prentice hall, Inc.

Hurlock, E. B. 1980. Psikologi Perkembangan: Suatu Pendekatan Sepanjang Rentang Kehidupan. Jakarta: Erlangga.

Jones, R. N. 2011. Teori dan Praktik Konseling dan Terapi. Yogyakarta: Pustaka Pelajar.

Nurbaity. 2012. Efektifitas Teknik Self Instruction dalam Mereduksi Stres Akademik. Skripsi. Bandung : UPI

Prasetyo, B. D. 2013. Keefektifan Teknik Self Instruction untuk Mengurangi Kecemasan Siswa dalam Menghadapi Ujian. Skripsi tidak diterbitkan. Malang: FIP UM.

Santrock, J. W. 2002. Life-Span Development: Perkembangan Masa Hidup. Jakarta: Erlangga.

Widiyanti, A. 2013. Keefektifan Teknik Self Insruction untuk Meningkatkan Self Efficacy dalam Belajar Siswa Kelas VII di SMP Negeri 3 Malang. Skripsi tidak diterbitkan. Malang: FIP UM. 